\title{
Национальный режим: генезис, доктрина и применение
}

\section{Тарасов O.A.*}

Под национальным режимом понимается такое правовое положение, при котором в государстве юридическим и физическим лицам другого государства предоставляются те же права и они несут те же обязанности, что и физические и юридические лица первого государства. Иными словами, иностранцы в широком смысле этого слова приравниваются к местным лицам ${ }^{1}$. Распространение на иностранцев общих правил и норм, действующих в данной стране в отношении собственных субъектов права, - хорошо известный в практике международных отношений юридический прием установления соответствующих прав ${ }^{2}$.

Зачатки понятия принципа национального режима можно наблюдать еще в книге «О праве войны и мира» Г. Гроция. Автор пишет о том, что «общее право согласно предположению относится к действиям, которые тот или иной народ предоставляет всем иностранцам наравне со своими гражданами. Ибо если при этом один какой-либо народ исключается, то ему этим причиняется несправедливость. Так, если иностранцам дозволено где-либо охотиться, ловить рыбу, птиц, собирать жемчуг, наследовать по завещанию, продавать вещи, заключать браки с женщинами даже тогда, когда в них нет недостатка, то одному народу нельзя воспретить этого иначе, как вследствие совершения преступления ${ }^{3}$. Г. Гроций неоднократно обращает внимание на наличие у иностранцев и местных граждан одинаковых прав и обязанностей: «если договор с гражданином заключает иностранец, он должен соблюдать местные законы, как любое лицо, заключившее договор, подобно подданному, подчиняющемуся действию местных законов» ${ }^{4}$.

- Тарасов Олег Александрович - аспирант ИГП РАН.

' СМ.: Богуславский М.М. Международное экономическое право, М., 1986. С. 117.

${ }^{2}$ Ануфриева Л.П. Международное частное право: в 3 томах. Том 1. Общая часть. М., 2000. С. 104-105.

${ }^{3}$ Гроций Г. О праве войны и мира: три книги, в которых объясняются естественное право и право народов, а также принципы публичного права. Пер. с лат. А.Л. Саккетти; Под общ. ред. С.Б. Крылова. М., 1994, книта 2, глава II, XXII. С. 213.

${ }^{4}$ Там же, книга 3, глава III, II.2. С. 217. 
В трактате Г. Гроция не только не говорится о национальном режиме как о специальном принципе международного экономического права, но и не употребляется даже терминов «национальный режим», «международное экономическое право», появление которых относится к XX веку. Тем не менее идея о предоставлении иностранным гражданам тех же прав и о несении ими тех же обязанностей, что и местными гражданами, есть не что иное, как проявление национального режима.

Другой ученый прошлого Э. де Ваттель в своей книге «Право народов или принципы естественного права, применимые к поведению и делам наций и суверенов» посвятил отдельную главу правилам в отношении иностранцев. Отмечены основные начала, на которых необходимо строить отношения с иностранными гражданами, коими являются человечность и справедливость. Э. де Ваттель пишет, что «даже в тех странах, на территорию которых иностранец может свободно вступить, полагают, что суверен допускает его под тем молчаливым условием, что иностранец будет подчинен законам (имея в виду общие законы, существующие для поддержания правопорядка и относящиеся не только к гражданину или подданному данного государства). Будучи подчинены законам местным, иностранцы, нарушившие их, должны быть наказаны в соответствии с законами страны. Цель наказания состоит в том, чтобы заставить уважать законы и поддерживать порядок и безопасность»5. В то же время Э. де Ваттель обращает внимание на важный момент в различии статуса гражданина и иностранца. «Иностранец, действительно, не может нести повинности, которые непосредственно связаны с качеством гражданина; но все другие повинности он должен в своей части выполнять» ${ }^{6}$. Автор довольно близко подходит к пониманию статуса иностранца, принятому в современной науке. Э. Де Ваттель пишет, что «право завещать или распорядиться своим имуществом на случай смерти является правом, вытекающим из права собственности, и по праву справедливости не может быть отнято у иностранца» ${ }^{7}$. Что касается вопроса о браках иностранцев, то Э. Де Ваттель считает: ничто не препятствует иностранцам заключать браки в государстве, однако отмечает и немало отступлений от данного правила. Так, например, подчеркивает автор, почти

\footnotetext{
${ }^{5}$ Де Ваттель Э. Право народов или принципы естественного права, применяемые к поведению и делам наций и суверенов. М., 1960. С. 271.

${ }^{6}$ Там же. С. 272.

${ }^{7}$ Там же. С. 273-275.
} 
во всех странах запрещалось вступать в брак с иностранцами, исповедующими другую религию, а в Швейцарии гражданину для вступления в брак с иностранкой необходимо представить доказательства того, что она принесет ему в приданое определенную сумму денег, установленную законом ${ }^{8}$.

Э. де Ваттель, так же как и Г. Гроций, не вводит понятия национального режима как режима, предоставляющего одинаковые права и закрепляющего одинаковые обязанности для иностранцев и местных граждан, но по сути пишет именно о национальном режиме.

В начале XX века широко распространена была концепция «минимального международного стандарта» (international minimum standard), «морального стандарта цивилизованных государств». В числе наиболее активных сторонников этой доктрины можно назвать Д. Анцилотти, А. Фердросса, Э. Борчарда, Л. Оппенгейма, П. Гугенхейма, Ш. ДеВишера и Ф. Джессопа.

Суть данной доктрины, по мнению А. Фердросса, заключается в том, что государства обязаны предоставлять установленный международным правом минимальный объем прав даже в том случае, если в виде исключения правовое положение иностранцев в какой-либо стране оказывается менее благоприятным по сравнению с режимом, предусмотренным международным правом ${ }^{9}$. Автор отмечает. что если в виде исключения правовой статус населения страны ниже минимального уровня по нормам международного права, то иностранцы могут оказаться в лучшем положении, чем местное население, так как по отношению к ним неприменимы нормы, стоящие ниже указанного минимального международно-правового уровня, при этом в процессуальном отношении положение иностранцев имеет еще то преимущество по сравнению с положением населения страны, что иностранцы находятся под зашитой своих дипломатических представителей ${ }^{10}$. А. Фердросс подчеркивает, что все права иностранцев, которые основываются на общем международном праве, исходят из общей идеи о том, что государства взаимно обязаны уважать в лице иностранца человеческое достоинство, в связи с чем обязаны наделять иностранцев необходимыми для достойного человеческого существования правами, которые, по мнению ученого, в соответствии с воззрениями культурных

${ }^{8}$ См.: Там же. С. 277.

${ }^{9}$ См.: Фердросс А. Международное право. М., 1959. С. 343.

${ }^{10}$ См.: Там же. С. 343. 
народов могут быть сведены к следующим пяти основным положениям: каждый иностранец признается субъектом права; приобретенные иностранцем частные права должны в принципе уважаться; иностранцам предоставляются основные свободы; иностранцам предоставляется право судебной защиты; иностранцы подлежат защите от преступных посягательств на их жизнь, свободу, имущество, честь".

А. Фердросс отдельно рассматривает сферу торгового права, отмечая, что многие торговые договоры фактически устанавливают далеко идущее уравнение иностранщев и собственного населения страны, что, по мнению ученого, дает возможность ряду авторов сделать неправомерный вывод о том, что таким уравнением иностранцев с собственным населением устанавливается более высокий международно-правовой уровень для иностранцев. А. Фердросс подчеркивает, что само заключение торговых договоров, уравнивающих статус иностранцев и местных граждан, нельзя рассматривать как желание государств отказаться от минимального международно-правового уровня прав иностранцев $^{12}$.

Также одним из сторонников доктрины минимального международного стандарта в отношении иностранцев является Л. Оппенгейм, который считает твердо установленным принципом, что «государство не может ссылаться на свое законодательство как на основание для аннулирования своих международных обязательств. На том же, по существу, основании государство, которому предъявлено обвинение в нарушении им его международных обязательств в отношении иностранцев, не может с надлежащим основанием сослаться на то, что, согласно его законодательству и практике, инкриминируемое ему действие не содержит дискриминации против иностранцев по сравнению с его собственными гражданами. Это в особенности относится к вопросу об обращении с иностранцами. Неоднократно указывалось, что по этому вопросу у цивилизованных народов существует стандартный минимум и что государство, которое не в состоянии держаться этого стандарта, подлежит международной ответственности» ${ }^{13}$.

При этом Л. Оппенгейм не исключает возможности уравнения иностранцев в правах и обязанностях с местным населением, подчеркивая, что каждое государство обязано согласно международному праву

"См: Там же. С. 344.

${ }^{12}$ См: Там же. С. 343-344.

${ }^{13}$ Оппенгейм Л. Международное право. М., 1949, т. I, полутом I, § 155 г. С. 321. 
устанавливать по крайней мере равенство иностранцев перед законом наряду с собственными гражданами, поскольку речь идет о защите их личности и имушества. Несмотря на вышесказанное автор отмечает, что фактически во всех странах при господстве экономического национализма ограничения для иностранцев носят более жесткий характер ${ }^{14}$.

Еще один приверженец доктрины минимального международного стандарта Ф. Джессоп в своей книге "A Modern Law of Nations" неоднократно ссылается на международный стандарт, отмечая, что защита иностранных граждан на территории другого государства должна осуществляться в соответствии с международным стандартом ${ }^{15}$.

Альтернативой минимальному международному стандарту явился стандарт (принцип) национального режима, который пользовался поддержкой многих юристов как в Европе, так и в Латинской Америке (К. Штрупп, Де Лутер, А. Альварец и др.), а принцип равенства статуса иностранцев и местных граждан выдвигался уже в 1868 г. аргентинским юристом К. Кальво. Принцип национального режима нашел применение в начале XX в. скольких решениях арбитражных судов, а также был подтвержден 17 государствами - участниками Гаагской конференции по кодификации международного права 1930 г. $^{16}$

Одним из первых ученых, кто детально рассмотрел соотношение двух стандартов: минимального международного стандарта и стандарта национального режима, стал Ян Броунли. Отмечая, что всегда пользовавшаяся поддержкой точка зрения о том, что иностранец может рассчитывать на равное к себе отношение по сравнению с местными гражданами на основании местного права, поскольку он подчиняется местным условиям со всеми вытекающими правами и обязанностями и поскольку наделение иностранца особым статусом противоречило бы принципам территориальной юрисдикции и суверенного равенства, Я. Броунли обращает внимание, что общепризнанной представляется и возможность возникновения определенных источников неравенства. Так, иностранец отнюдь не наделяется всеми политическими правами в стране пребывания, воспринимает местное право таким, какое оно есть в части, касающейся экономической деятельности и существующих в отношении иностранца ограничений заниматься определенными профессиями; доступ иностранца в суд может быть открыт с неко-

${ }^{14}$ См.: Там же, т. I, полутом II, § 320. C. 249-251.

${ }^{15}$ See: Jessup P.C. A Modem Law of Nations. New York, 1952. P. 102.

${ }^{16}$ См.: Броунли Я. Международное право. М., 1977, т. 2. С. 205. 
торыми дополнительными процедурными правилами (например, у иностранца могут потребовать внесения залога в обеспечение судебных издержек) ${ }^{17}$.

Рассматривая перспективы развития минимального международного стандарта, Я. Броунли обращает внимание на возникшие в середине 20 века попьтки синтезировать концепцию прав человека с принципами, регулирующими обращение с иностранцами. Автор ссылается на Гарсия Амадора, докладчика Комиссии международного права по вопросу об ответственности государств, который представил в своем докладе проект главы «Нарушение основных прав человека», суть ее заключается в том, что на государство возлагается обязанность обеспечить иностранцам пользование теми же гражданскими правами и предоставить им те же индивидуальные гарантин, которыми пользуются его собственные граждане, однако эти права и гарантии не могут быть ни в коем случае меньшими, нежели «основные права человека», признанные и определенные в современных международньх документах ${ }^{18}$.

По мнению Я. Броунли, минимальный стандарт крайне двусмыслен и расплывчат, а проект, представленный Г. Амадором, подразумевает, что гражданские права и свободы «могут быть подвергнуты таким ограничениям, которые прямо выраженным образом установлены законом в интересах внутренней безопасности, экономического благосостояния нации, публичного порядка, здоровья или морали или во имя обеспечения уважения к правам и свободам друтих лиц» ${ }^{19}$.

Главные недостатки концепции минимального международного стандарта, по мнению Я. Броунли, заключаются в том, что стандарт отдельной экономической или социальной системы порой выдается за универсально справедливый стандарт; в государствах с западным образом цивилизации применялись далеко не лучшие стандарты за последние годы. Стоит согласиться с ученым в том, что единого стандарта вообще не существует, и нельзя возводить в постулат «некий минимальный стандарт», который на деле поддерживает определенную философию экономической жизни за счет интересов государства пребывания ${ }^{20}$.

Нельзя не согласиться с Я. Броунли, что доктрина минимального международного стандарта имеет ряд кардинальных недостатков и пробелов и отражает интересы определенной группы государств.

${ }^{17}$ См.: Там же. С. 204.

${ }^{18}$ Tам же. C. 208-209

${ }^{19}$ См.: Там же. С. 209.

${ }^{20}$ См.: Там же. С. 209-210. 
Г.М. Вельяминов отмечает, в частности, что «оценка «справедливого и равного режима» для иностранных инвестиций в качестве составной части действительно признанной международной обычноправовой нормы о минимальном стандарте режима иностранцев весьма спорна и есть не более чем доктринальное толкование» ${ }^{21}$. Г.М. Вельяминов таюже подчеркивает, что даже такой, казалось бы, «минимум», как трудоустройство, иностранным гражданам международным правом отнюдь не обеспечивается, не говоря уже об обеспечении права на инвестирование, гораздо менее подходящее под минимальный стандарт, чем право просто трудиться ${ }^{22}$.

В связи с вышеизложенным концепция национального режима иностранным гражданам представляется наиболее юридически объективной и оправданной. Хотя в истории применения принципа национального режима в области экономической деятельности можно найти немало злоупотреблений.

M.M. Богуславский, исследуя международную практику применения национального режима, отмечает, что США и рядом западных стран данный принцип применялся в интересах собственных монополий, поскольку в условиях экономического неравенства предоставление национального режима более сильному иностранному партнеру (например, в области разработки природных богатств, добычи нефти и др.) означает фактически предоставление ему больших преимушеств, чем национальным фирмам, что и делает использование данного принципа «одним из грозных орудий неоколониализма» 23.

В одной из современных работ по международному экономическому праву (Д. Карро и П. Жюйара) национальный режим называется «естественной вершиной режима наиболее благоприятствуемой нации, если речь идет о том, чтобы реализовать главный в международной торговле принцип - принцип недискриминации». Авторы исходят из того, что в свете организации международной торговли, основанной на свободе и недискриминации, клаузула о наиболее благоприятствуемой нации и клаузула о национальном режиме не могут обойтись друг без друга: клаузула о национальном режиме существенно усиливает клаузулу о наиболее благоприятствуемой нации, а поскольку обе клаузулы часто взаимодополняют друг друга в двусторонних договорах

${ }^{21}$ Вельяминов Г.М. Международное экономическое право и процесс (Академический курс). М., 2004. С. 361.

${ }^{22}$ См.: Там же. С. 361.

${ }^{23}$ Богуславский М.М. Указ. соч. С. 117. 
о торговле, заключающихся между государствами, то обе клаузулы представляют собой две ключевые опоры первоначально ГАТТ, а ныне всей системы $\mathrm{BTO}^{24}$. Д. Карро и П. Жюйар также обращают внимание на применение клаузулы о национальном режиме в сфере действия международных соглашений по вопросам защиты прав на интеллектуальную собственность.

Г.М. Вельяминов считает, что национальный режим в некотором смысле можно трактовать как особую разновидность режима наибольшего благоприятствования: а именно предоставление иностранным лицам одного из государств - благоприятствования, но не такого же, как иностранным лицам другого, третьего государства, а такого, как своим собственным лицам ${ }^{25}$.

Еще один из ведущих зарубежных современных правоведов Джон Джексон также отмечает, что национальный режим является вторым важнейшим «недискриминирующим режимом» после режима наиболее благоприятствуемой нации и первоначально был выражен в статье 3 ГАТТ $^{26}$. Д. Джексон отмечает, «что в то время как режим наиболее благоприятствуемой нации требует равного обращения в товарами различных государств, национальный режим требует таких условий для импортируемых товаров, как упрощение процедур на границе и таможне, при которых импортируемые товары не находились бы в худших условиях, чем товары местного производства» ${ }^{27}$.

Д. Джексон и другие американские ученые (К. Дам, У. Дэйви), считают что принцип национального режима способствует реализации принципа недискрминации импортируемых товаров по отношению к товарам местного производства, при этом национальный режим занимает центральное место в правилах и политике международной торговли, а также существует внутри системы ГАТТ для того, чтобы предотвратить практику уклонения правительств от тарифных обязательств ${ }^{28}$.

${ }^{24}$ См.:Карро Д., Жюйар.П. Международное экономическое право. М., 2002. C. 195-196.

${ }^{25}$ Вельяминов Г.М. Указ. соч. С. 109.

${ }^{26}$ See: Jackson J. H. The World Trading System: Law and Policy of International Economic Relations 2nd Ed, London. 1999. P. 213.

${ }^{27}$ Op. cit. P. 213.

${ }^{28}$ See: Jackson J.H., Davey W.J., Sykes A.O. Legal Problems of International Economic Relations: Case, Materials and Text. 3rd ed., St. Paul, Minn., 1995, ch.11, P. 501; Dam K.W. The GATT: Law and International Economic Organization, (University of Chicago Press 1970), ch. 7, P. 278. 
В советской науке упоминание о национальном режиме при рассмотрении сферы торговых отношений можно встретить уже в первом послевоенном издании по международному праву: «национальный режим, в силу которого иностранцам в области торговли данного государства предоставляются за некоторыми исключениями почти весь комплекс прав, которые закреплены законами страны за ее гражданами и юридическими лицами, нередко встречается наряду с принципом наибольшего благоприятствования» ${ }^{29}$.

Аналогичное положение можно найти и в работах В.И. Лисовского, который отмечает, что нередко в международных торговых договорах и соглашениях устанавливается нормативное положение (условие) о том, что юридические лица и граждане договаривающихся сторон при совершении ими внешнеторговых операций взаимно пользуются (режим торговли, порядок оформления сделок, таможенное обложение, режим торговых судов в портах и т.д.) правами местных граждан (данной договаривающейся стороны), т.е. на них распространяется национальный режим ${ }^{30}$.

Как пишет В.М. Шумилов, многие правоведы выделяют из перечисленных принципов группу принципов, включающую принципы национального режима, преференциального режима, наиболее благоприятствуемой нации и др., указывая либо на их конвенционный характер, либо квалифицируя в качестве правовых режимов, а не принципов $^{31}$. Специфика этих принципов, по мнению В.М. Шумилова, «состоит в том, что в них заложен метод сопоставления и уравнивания условий: принцип нанбольшего благоприятствования требует уравнения с наилучшими условиями; принцип недискриминации запрещает отказывать в предоставлении общих для всех условий; принцип национального режима требует уравнивания с условиями, созданными для внутренних (национальных) субъектов права и т.п.» ${ }^{32}$. Соответствуюшие принципы трактуются автором в качестве «правовых трафаретов», «технико-правовых приемов» или стандартов. С од-

${ }^{29}$ Международное право. Под обш. ред. В.Н. Дурденевкого и С.Б. Крылова. М., 1947. C. 440-441.

${ }^{30}$ См.: Лисовский В.И. Международное торговое и финансовое право. М., 1974. С. 29; Лисовский В.И. Правовое регулирование международных экономических отношений. М., 1984. С. 96.

${ }^{3 \prime}$ См.: Шумилов В.М. Международное экономическое право в эпоху глобализации. М., 2003. С. 85.

${ }^{32}$ Там же. C. 86. 
ной стороны, эти стандарты универсальны и применяются к той или иной материальной сфере по мере необходимости или в зависимости от требований международного права (международного экономического права). С другой стороны, каждый такой стандарт связан с определенными притязаниями, требованиями, правами и обязанностями, и с этой точки зрения, является принципом международного права (международного экономического права). В данном случае характер притязаний, а также объем прав и обязанностей определяются не чем иным, как другими нормами права. Например, принцип наиболее благоприятствуемой нации порождает права и обязанности по уравниванию условий в сравнении с наилучшими условиями, а объем этих прав и обязанностей, сфера применения метода уравнения (например, к тарифной сфере) может оговариваться сторонами в двустороннем соглашении, а может вытекать из международного обычая.

Именно в этой двойственности стандартов-принципов и заключается специфика принципов наиболее благоприятствуемой нации, недискриминации, предоставления национального режима, преференциального режима и др.

Таким образом, В.М. Шумилов делает вывод, что вышеперечисленные принципы составляют особую группу принципов-стандартов, материальное наполнение или сфера приложения которых зависит от других норм международного права (международного экономического права), а также от внутригосударственного правового режима, связанного с товарами, финансами, инвестициями, рабочей силой ${ }^{33}$.

Принцип национального режима относится к специальным принципам международного экономического права, перечень которых, соглашаясь с Г.М. Вельяминовым, нужно ограничить следуюшими принципами: недискриминация, взаимная выгода, режим наиболее благоприятствуемой нации, национальный режим, преференциальный режим; причем все эти принципы носят конвенционный характер ${ }^{34}$.

Обратимся к практике и рассмотрим некоторые документы, в которых зафиксирован принцип национального режима. Отечественная договорная практика до сих пор относится в общем сдержанно к применению национального режима в области торговли. Национальный режим применяется в торговых договорах в ограниченном числе слу-

${ }^{33}$ См.: Там же. С. 86.

${ }^{34}$ См.: Вельяминов Г.М. Основы международного экономического права. М., 1994. C. $20-23$. 
чаев, например по некоторым вопросам торгового мореплавания. Так, в ст. 18 Договора о торговле и мореплавании между СССР и Норвегией от 15 декабря 1925 г. говорится о предоставлении национального режима «судам договаривающихся сторон, их экипажам, грузам и пассажирам в портах другой стороны, либо при их прибытии, либо во время их пребывания, либо при отплытии и вообще во всем, что касается судоходства» ${ }^{35}$. Можно также найти упоминание о национальном режиме в одном из первых послевоенных договоров - в Мирном договоре с Финляндией от 10 февраля 1947 г., который был ратифицирован СССР и вступил в силу для нашей страны 15 сентября 1947 г. Так, в пП. «с» П. 1 ст. 31 указанного договора говорится о том, что гражданам Объединенных Наций, в том числе юридическим лицам, должен быть предоставлен национальный режим и режим наибольшего благоприятствования во всех вопросах, касающихся торговли, промышленности, мореплавания и других видов торговой деятельности в Финляндии ${ }^{36}$. В торговых договорах СССР с некоторыми государствами (Югославией, Японией) закреплено, что в случае, если судно одной из договаривающихся сторон потерпит бедствие или кораблекрушение у берегов другой договаривающейся стороны, то судно и груз будут пользоваться теми же преимуществами и льготами, которые предоставляются этой договаривающейся стороной национальному судну и его грузу, т.е. речь идет о предоставлении национального режима в отношении иностранного судна и груза ${ }^{37}$.

Предоставление национального режима в отечественной практике предусматривается в отношении свободного доступа иностранных юридических лиц и граждан в суды. При этом граждане и юридические лица каждой из договаривающихся сторон будут пользоваться на одинаковых условиях с местными гражданами и юридическими лицами правом заявлять исковые требования, отстаивать и защищать свои интересы в судах ${ }^{38}$.

${ }^{35}$ Договор между СССР и Норвегией о торговле и мореплавании от 15.12 .1925 г. ст. 18 // Сборник торговых договоров и соглашений по торгово-экономическому сотрудничеству СССР с иностранными государствамн. М., 1977, т. II. С. 18.

${ }^{36}$ См.: Мирный договор с Финляндией оr 10.02 .1947 п. 1. ст. 31 ; СССР ратифицировал договор (Указ Президиума ВС СССР от 29.08.1947 г.), ратификационная грамота депонирована 15.09.1947 г. // http://www.pereplet.ru/history/Europe/Finland/mirFin.html .

${ }^{37}$ Договор о торговле и мореплавании между СССР и Королевством Югославии от 11 мая 1940 г. ст. VII; См.: Торговый договор между СССР и Японией от 6 декабря 1957 г. ст. 10 // См.: Сборник торговых договоров и соглашений по торгово-экономическому сотрудничеству СССР с иностранными государствами. М., 1977, т. II С. 391, 429-430. 
Еще одним важным документом в плане развития сотрудничества и торговли для России является Соглашение о торговых отношениях между СССР и США, подписанное 1 июня 1990 г. (вступило в силу для России и США 17 июня 1992 г.). Особенность данного соглашения видится в свете окончания «холодной войны» между двумя сверхдержавами и началом нового этапа в экономических отношениях между странами.

Принимая во внимание взаимовыгодность торговых отношений между двумя странами и исходя из развития рыночного механизма в СССР и его более тесных отношений с ГАТТ, в П. 1 ст. II данного соглашение было закреплено важное для Советского Союза (а впоследствии - и для России) положение о том, что будут создаваться возможности для постепенного увеличения предоставления национального режима для товаров и услуг Соединенных Штатов ${ }^{39}$. Так, стороны хотя бы в общем виде закрепили принцип национального режима, который наряду с принципами наиболее благоприятствуемой нации и недискриминации был положен не только в основу данного соглашения, но и в развитие экономических отношений между государствами. Однако Г.М. Вельяминов отмечает, что в данном соглашении режимы наиболее благоприятствуемой нации и недискриминации, будучи формально равными для сторон, фактически не обеспечивают реального наибольшего благоприятствования и равной взаимной выгоды (фактически на товарных рынках США конкуренты российских поставщиков пользуются большими преимуществами, чем российские поставщики $)^{40}$.

Советский Союз и США закрепили национальный режим для граждан, компаний и организаций любой из Сторон при обращении в любые суды и административные органы на территории другой Стороны в качестве истцов, ответчиков или в каком-либо ином качестве ${ }^{41}$. Ана${ }^{38}$ Договор о торговле и мореплавании между СССР и Итальянской республикой от 11 декабря 1948 г., ст. 19; См.: Договор о торговле и мореплавании между СССР и Ираном от 25 марта 1940 г., ст. 8 // См.: Сборник торговых договоров и соглашений по торгово-экономическому сотрудничеству СССР с иностранными государствами. М., 1977 , т. I. C. $361,306$.

${ }^{39}$ См.: Соглашение о торговых отношениях между Союзом Советских Социалистических Республик и Соединенными Штатами Америки (Вашингтон, 1 июня 1990 г.), ст. II, п. $1 / /$ http://www.wto.ru/ru/content/documents/sogl/2rus-usa.doc

${ }^{40}$ См.: Вельяминов Г.М. Международное экономическое право и процесс. С. 111-113.

${ }^{41}$ См.: Соглашение о торговых отношениях между Союзом Советских Социалистических Республик и Соединенными Штатами Америки (Вашингтон, 1 июня 1990 г.), ст. XII, п. 1. 
логичное полюжение содержится в Соглашении о торговле и экономическом сотрудничестве между'Россией и Норвегией от 26 марта 1946 г. и в Соглашении о торговых отношениях со Швецией от 04 февраля 1993 г.4 $^{42}$

Среди заключенных Российской Федерагией торговых соглашений стоит выделить Соглашение со Швейцарией - одно из немногих содержащих принцип предоставления национального режима «товарам, происходящим с территории одной договаривающейся стороны и ввозимым на территорию другой договаривающейся стороны, в отношении внутренних налогов и внутренних сборов и всех законов, правил, требований, касающихся продажи этих товаров на внутреннем рынке, предложений на их продажу, покупку, транспортировку, распределение или использование» ${ }^{43}$. Аналогичные положения о национальном режиме содержатся также в Торговом Соглашении с Коста-Рикой от 28 ноября $1997 \Gamma^{44}$.

Стоит обратить внимание на такой важный для России документ, как Соглашение о партнерстве и сотрудничестве от 24 июня 1994 г. между Росспей и Евросоюзом. Профессор Левенского Университета Э. Де Смайтер отметил: «Стабильная, демократическая и процветающая Россия, прочно связанная с объединенной Европой без границ, необходима для обеспечения продолжительного мира на континенте» ${ }^{45}$. Однако Г.М. Вельяминов отмечает, что Евросоюз не уступает и даже отчасти превосходит США в качестве жесткого и неуступчивого партнера России, в частности при переговорах о вступлении в ВТО. Евросоюз требует повышения внутренних цен на энергоносители, при этом

42 См.: Соглашение между Правительством Российской Федерации и Правительством Королевства Норвегия о торговле и экономическом сотрудничестве от 26.03.1996 r., ст. 11 // Дипломатический вестник. 1996. № 4. С. 15-18; Соглашение между Правительством Российской Федерации и Правительством Королевства Швеция о торговых отношениях от 04.02.1993 г.., ст. 8 // http://npa-gov.garweb.ru:8080/public/ default.asp?no $=2455349$.

${ }^{43}$ Соглашение о торговле и экономическом сотрудничестве между Российской Федерацией и Швейцарской Конфедерацией от 12.05 .1994$, ст. 5 // Бюллетень международных договоров. 1995. № 1. С. 51-62.

${ }^{4}$ См.: Торговое соглашение между Правительством Российской Федерации и Правительством Республики Коста-Рика, ст. 4 // http://npa-gov.garweb.ru:8080/public/ default.asp?no=2460126.

${ }^{45}$ Де Смайтер Э. Россия и Европейский союз: история и перспективы сотрудничества (заметки европейского эксперта) // http://eulaw.edu.ru/documents/articles/ rus_es_perspeci.htm. 
фактическая задача Евросоюза - получить доступ к российским ресурсам газа ${ }^{46}$. Тем не менее принцип национального режима в Соглашении России с Евросоюзом представлен более широко, нежели в упомянутом Соглашении о торговых отношениях СССР с США.

Принцип национального режима наряду с принципом наиболее благоприятствуемой нации является в Соглашении о партнерстве и сотрудничестве с Евросоюзом ключевым принципом. В соответствии с п. 3 ст. 28 настояшего Соглашения Россия, за исключением изъятий, перечисленных в Приложении 4 к Соглашению, предоставляет, при соблюдении своего законодательства и иных нормативных актов, дочерним компаниям Сообщества в России в отношении их деятельности режим не менее благоприятный, чем режим, который предоставляется иным российским компаниям, или режим, предоставляемый российским компаниям, являющимся дочерними компаниями компаний любой третьей страны, в зависимости от того, какой из них лучше ${ }^{47}$.

Такие изъятия сделаны Россией в сфере использования подземных и природных ресурсов, включая добычу (например, может требоваться концессия на добычу некоторых руд и металлов компаний, не контролируемых российскими компаниями); рыболовства (требуется разреш்ение компетентного правительственного органа на рыболовство); приобретения и торговли недвижимостью (к примеру, компаниям, не контролируемым российскими компаниями, не разрешается покупать участки земли, однако они могут арендовать землю на период не более 49 лет); связи (имеются ограничения в области услуг связи, включая услуги мобильной и спутниковой связи, разработку, установку, эксплуатацию и обслуживание средств связи). Кроме того, Россией сделаны ограничения для иностранного участия в деятельности средств массовой информации, в отношении некоторых видов профессиональной деятельности, относительно аренды федеральной собственности ${ }^{48}$.

Кроме этого, положения о национальном режиме, содержащиеся в ст. 28 Соглашения о партнерстве и сотрудничестве между Россией и Евросоюзом, применяются в отношении банковских услуг (принятие депозитов и прочих возвратных средств от населения, кредитова-

${ }^{46}$ См.: Вельяминов Г.М. Указ. соч. С. 145.

${ }^{47}$ См.: Соглашение о партнерстве и сотрудничестве, утверждающее партнерство между Российской Федерацией, с одной стороны, и Европейскими сообществами и их государствами-членами, с другой стороны, от 24 июня 1994 г., ст. 28, п. 3 // http:// www.wto.ru/ru/content/documents/sogl/1 sps.doc.

${ }^{48}$ См.: Там же, прил. 4. 
ние всех видов, включая потребительский кредит, залоговый кредит, факторинг и финансирование коммерческих сделок) и страховых услуг (в частности, прямое страхование, перестрахование и ретроцессия, страховое посредничество). Причем в отношении банковских услуг, указанных в части «В» Приложения 6 к Соглашению, национальный режим, предоставляемый Россией, означает режим не менее благоприятный, чем тот, который предоставляется Россией собственным компаниям с рядом изъятий, отмеченных в Приложении 7 к данному Соглашению. Так, например, Россия оставляет за собой право устанавливать в отношении российских дочерних компаний Сообщества минимальный размер капитала больше, чем тот, который устанавливается для ее собственных компаний, при условии, что этот минимальный размер капитала не будет увеличен по сравнению с тем, который установлен на дату подписания настоящего соглашения, до тех пор, пока в отношении минимального размера капитала не начнет применяться национальный режим ${ }^{49}$.

Особенно стоит подчеркнуть, что Россия и Евросоюз признают важность предоставления друг другу национального режима в отношении учреждения и, где это не предусматривается в настоящем соглашении, деятельности компаний друг друга на их территории и соглашаются рассмотреть возможность продвижения к этой цели на взаимоприемлемой основе и в свете любых рекомендаций Совета сотрудничества ${ }^{50}$.

Национальный режим в Соглашении о партнерстве и сотрудничестве между Россией и Евросоюзом предусмотрен также для доступа в судебные и административные органы; в отношении обложения товаров, поступающих с территории одной договаривающейся стороны на территорию другой, внутренних налогов и сборов любого рода и в отношении всех законов, правил и требований, затрагивающих продажу данных товаров на внутреннем рынке, покупку и транспортировку. Кроме того, каждая из Сторон по данному соглашению предоставляет для судов, используемых для транспортировки товаров, пассажиров или и тех, и других и плавающих под флагом другой стороны, режим не менее благоприятный, чем режим, предоставляемый стороной своим судам, в отношении доступа к портам, открытым для иностранных судов, использования инфраструктуры и связанных с морс-

\footnotetext{
${ }^{49}$ См.: Там же, прил. $6,7$.

${ }^{50}$ См.: Там же, ст. 33.
} 
кими перевозками вспомогательных услуг, предоставляемых этими портами, так же как и в отношении соответствующих сборов и платежей, таможенного обслуживания, предоставления причалов и возможностей погрузки и разгрузки ${ }^{51}$.

В связи с перспективой вступления России в ВТО, очевидно, отношение к применению принципа национального режима в российской практике должно измениться в сторону его более широкого распространения, поскольку данный принцип является одним из столпов системы ВТО, закреплен во многих соглашениях, заключенных в рамках ВТО (ГАТТ, ГАТС, ТРИМС, ТРИПС и др.).

Здесь уместно кратко изложить содержание статьи III ГАТТ (центральной о национальном режиме в рамках ГАТТ). Так, п. 1 данной статьи устанавливает общий принцип, согласно которому «внутренние правила количественного регулирования, требующие смешения, переработки или использования товаров в определенных количествах или долях, не должны применяться к импортированным или отечественным товарам таким образом, чтобы создавать защиту для отечественного производства». Пункт 2 говорит о применении национального режима в отношении внутреннего налогообложения ввозимых товаров («товары с территории любой договаривающейся стороны, ввозимые на территорию другой договаривающейся стороны, не подлежат обложению, прямо или косвенно, внутренними налогами или иными внутренними сборами любого рода, превышающими, прямо или косвенно, налоги и сборы, применяемые к аналогичным отечественным товарам»), в то время как п. 4 устанавливает национальный режим в отношении торговли и использования импортируемых товаров в целом («товарам с территории любой договаривающейся стороны, ввозимым на территорию другой договаривающейся стороны, предоставляется режим не менее благоприятный, чем тот, который предоставлен аналогичным товарам отечественного происхождения в отношении всех законов, правил и требований, затрагивающих их внутреннюю продажу, предложение к продаже, покупку, транспортировку, распределение или использование») ${ }^{52}$. Другие пункты содержат специальные положения о национальном режиме, за исключением п. 8, устанавливаюшего, что правила статьи III не применяются к законам,

'І См.: Там же, ст. 11, 39.

${ }^{52}$ Генеральное соглашение по тарифам и торговле (ГАТТ 1947) // http://www.wto.ru/ru/ content/documents/docs/gatt47ru.doc 
требованиям, регулирующим закупки правительственными учреждениями товаров, приобретаемых для правительственных целей.

Национальный режим применяется в договорах о правовой помощи, социальном обеспечении (судебная защита, предоставление трудовых и иных прав на основе национального режима). Например, соглашение между правительствами России и Украины о трудовой деятельности и социальной защите граждан России и Украины, работающих за пределами своих государств, от 14 января 1993 г. исходит из принципа национального режима, предусматривает взаимное применение трудового законодательства к гражданам обоих государств, порядок возмещения ущерба работнику вследствие увечья либо иного повреждения здоровья, полученного в связи с исполнением им трудовых обязанностей ${ }^{53}$.

Иначе в отечественной договорной практике решается вопрос о применении национального режима в области авторского права и прав на изобретения и товарные знаки. В этих сферах предоставление в РФ иностранцам данного принципа приобрело большое практическое значение.

Бернская конвенция об охране литературных и художественных произведений 1886 г. в редакции 1971 г., действующая для России с 13 августа 1995 г., Всемирная (Женевская) конвенция об авторском праве 1952 г., к которой СССР присоединился в 1973 г., исходят из принципа национального режима. В соответствии со ст. 5, 14, 15 Бернской конвенцией субъекту охраны предоставляется национальный режим, то есть те же права, которые предоставляются соответствующими законами гражданам данной страны, в отношении судебной защиты, гражданину каждой страны Бернского Союза в любой другой стране Союза также обеспечен национальный режим ${ }^{54}$.

Во Всемирной конвенции об авторском праве 1952 г. принцип национального режима, по мнению М.М. Богуславского, играет большую роль, поскольку данный документ содержит не много материальных норм, отсылая к внутреннему законодательству, то есть присоедине${ }_{53}$ См.: Соглашение между Правительством России и Правительством Украины о трудовой деятельности и социальной защите граждан России и Украины, работающих за пределами границ своих государств от 14.01 .1993 г. ст. 6, ст. 9 // http://sc.fss.ru/biblio/ archive/normdoc_sogl/

${ }^{54}$ См.: Бернская конвенция об охране литературных и художественных произведений 1886 г. Парижский акт от 24.07 .1971 г., п. 3 ст. 5, ст. 14, ст. 15 // http://www.fips.ru/avp/ law/inter/berne.htm. 
ние к конвенции в меньшей степени требует внесения изменений во внутреннее законодательство ${ }^{55}$. Правило о национальном режиме в П. 1 ст. II Всемирной конвенции выражено следуюшим образом: «Выпушенные в свет произведения граждан любого договаривающегося государства, равно как и произведения, впервые выпушенные в свет на территории такого государства, пользуются в каждом другом договаривающемся государстве охраной, которую такое государство предоставляет произведениям своих граждан, впервые выпушенным в свет на его собственной территории» ${ }^{56}$. Аналогичное правило действует и в отношении произведений, не выпущенных в свет.

26 мая 2003 г. Россия стала участницей Римской Конвенции об охране интересов артистов-исполнителей, производителей фонограмм и вещательных организаций от 26 октября 1961 г. Согласно п. 1 ст. 6 данного международного документа каждое договаривающееся государство предоставляет вещательной организации национальный режим охраны при соблюдении любого из условий: штаб-квартира вешательной организации расположена в другом договаривающемся государстве; передача в эфир осуществлена с помощью передатчика, расположенного в другом договариваюшемся государстве ${ }^{57}$.

Особо надо сказать о двусторонних соглашениях по авторскому праву между государствами, в основу которых кладется принцип национального режима. Например, в Соглашении СССР и Польши о взаимной охране авторских прав от 4 октября 1974 г. говорится, что каждая договаривающаяся сторона признает авторские права граждан и организаций другой договаривающейся стороны и их правопреемников на произведения науки, искусства, литературы вне зависимости от места их первого опубликования, а также авторские права граждан третьих стран и их правопреемников на произведения, впервые выпушенные в свет на территории СССР или Польши, и обеспечивает «охрану этих прав на тех же основаниях и условиях, какие установлены ее законодательством в отношении собственных граждан» ${ }^{58}$.

${ }^{55}$ Богуславский М.М. Международное частное право. М., 2000. С. 264.

${ }^{56}$ Всемирная (Женевская) конвенция об авторском праве от 06.09. 1952 г., п. 1, ст. II // См.: Собрание Постановлений СССР. 1973. № 24 ст. 139.

${ }^{57}$ См.: Международная Конвенция об охране интересов артистов-исполнителей, производителей фонограмм и вещательных организаций (Рим, 26.10.1961г.), п. 1, ст. 6 // http://www.intemet-law.ru/law/int/rus_in05.htm .

${ }^{58}$ Соглашение между СССР и Польшей о взаимной охране авторских прав от 04.10.1974 г., ст. 2 // См.: Авторское право: нормативные акты. Национальное законодательство и международные конвенции. Сост. И. Силонов. М., 1998. 
Таким образом, содержание данного Соглашения конкретизирует положения вышеперечисленных международных конвенций по международному авторскому праву. Аналогичные соглашения были заключены Советским Союзом с Венгрией, ГДР, Болгарией, Чехословакией, Кубой, Австрией, Швецией.

В одностороннем порядке в СССР национальный режим предоставлялся иностранцам в отношении защиты их прав ${ }^{59}$. Современное российское законодательство во многом повторяет и развивает положения об иностранных гражданах, закрепленные в советском законодательстве. В этой связи предоставление национального режима в одностороннем порядке иностранным гражданам, закрепленное во внутреннем законодательстве РФ, является важным шагом не только в развитии заложенных идей и основ законодательства СССР, но и тенденцией к более широкому применению принципа национального режима.

Во внутреннем законодательстве РФ принцип национального режима в общей форме закреплен в отношении иностранцев на конституционном уровне: «иностранные граждане и лица без гражданства пользуются в РФ правами и несут обязанности наравне с гражданами Российской Федерации» (ч. 3 ст. 62 Конституции РФ) ${ }^{60}$. В силу данного положения по общему правилу иностранные граждане и лица без гражданства равны в правах и обязанностях с российскими гражданами. Принцип национального режима сформулирован более широко: в отличие, от Закона СССР этот принцип подлежит применению не только к иностранным гражданам, но и к лицам без гражданства. Исключения устанавливаются федеральным законом и международным договором РФ, аналогичное положение содержится и в ГК РФ.

Таюже принцип национального режима предусматривается и в других нормативных документах РФ, закрепляя за определенными исключениями равенство прав и обязанностей российских граждан и иностранцев: в Гражданском кодексе РФ, Гражданском процессуальном кодексе РФ, Арбитражном процессуальном кодексе РФ, Законе о правовом положении иностранных граждан в РФ, Законе об авторском праве.

${ }^{59}$ См.: Лунц Л.А. Курс международного частного права. Особенная часть. М., 1975. С. 12-40; Лунц Л.А., Марышева Н.И., Садиков О.Н. Международное частное право. М., 1984. С. 81-89; Богуславский М.М. Указ. соч. С. 106-112.

${ }^{60}$ Конституция Российской Федерации (принята 12.12 .1993 г.), ст. 62 // «Российская газета» от 25.12.1993 г. № 237. 
Так, ст. 2 ГК РФ определяет, что правила, установленные гражданским законодательством, применяются к отношениям с участием иностранных граждан, лиц без гражданства и иностранных юридических лиц, если иное не предусмотрено федеральным законом; в соответствии со ст. 1196 ГК РФ иностранные граждане пользуются в Российской Федерации гражданской правоспособностью наравне с российскими гражданами, кроме случаев, установленных законом ${ }^{61}$. Если рассмотреть сферу процессуальных прав, то ст. 398 ГПК РФ иностранным гражданам и организациям предоставляет право обращаться в суды в РФ для защиты своих нарушенных или оспариваемых прав, свобод и законных интересов, при этом иностранные лица пользуются процессуальными правами и выполняют процессуальные обязанности наравне с российскими гражданами и организациями ${ }^{62}$. Также национальный режим закреплен в ст. 254 АПК РФ, согласно которой иностранные лица несут процессуальные права и пользуются процессуальными обязанностями наравне с российскими организациями и гражданами. Процессуальные льготы предоставляются иностранным лицам, если они предусмотрены международным договором РФ ${ }^{63}$. В области авторского права на основании ст. 5 Закона РФ об авторском праве и смежных правах иностранцы пользуются авторским правом на произведения, впервые появившиеся в РФ или находящиеся на ее территории в какой-либо объективной форме, на одинаковых основаниях с нашими гражданами ${ }^{64}$.

Таким образом, в приведенных выше примерах речь идет о предоставлении национального режима иностранным гражданам в РФ в одностороннем порядке в отдельных сферах.

Подводя итоги, можно отметить следующее:

1. Принцип национального режима прошел долгий эволюционный путь: о национальном режиме говорили, по сути, на заре нового времени еше Г. Гроций и Э. де Ваттель. О равных правах и обязанностях иностранцев и местных граждан в XVII-XVIII веках можно было го-

${ }^{61}$ См.: Гражданский кодекс РФ (часть 3) от 26.11 .2001 г. № 146-Ф3, ст. 2, ст. 1196 // «Российская газета» от 28.11.2001г. № 233.

${ }^{62}$ См.: Гражданский процессуальный кодекс РФ от 14.11.2002 г. № 138-Ф3, ст. 398 // «Российская газета» от 20.11.2002. № 20.

${ }^{63}$ См.: Арбитражный процессуальный кодекс Российской Федерации от 24.07 .2002 г. № 95-Ф3, ст. 254, п. 1. // Парламентская газета, № 140-141, 27.07.2002 г.

${ }^{6}$ См.: Закон РФ от 9 июля 1993 r. № 5351-I «Об авторском праве и смежных правах» (с измен. от 19.07.1995 г), ст. $5 / /$ http://www.febras.ru/ patent/copyright/2_3part2,html . 
ворить лишь с большой долей условности, поскольку такое равенство стало признаваться лишь «цивилизованными народами» и в ограниченных сферах. Идеи, выдвинутые данными авторами, были несомненно прогрессивными и во многом легли в основу современной доктрины международного права о национальном режиме.

2. Концепция международного минимального стандарта, господствующая в начале XX века, поддержанная ведущими западными международными правоведами (А. Фердроссом, Л. Оппенгеймом и др.), конечно, в первую очередь отражала интересы своего времени и определенных государств (например, минимальный стандарт использовался промышленно развитыми странами-инвесторами для пресечения национализации капиталовложений со стороны развивающихся странимпортеров). Эта концепция в силу своей субъективности имеет ряд существенных недостатков: нет единого международного стандарта, весьма сомнительны критерии справедливости и универсальности стандарта и т.д. А главное - принцип минимального стандарта не получил широкого применения в международных правовых актах универсального характера. Даже в двусторонних соглашениях о поошрении и защите инвестиций национальный режим применяется гораздо чаще, нежели минимальный стандарт. В середине XX века сформировалась новая отрасль международного права - международное экономическое право, в основу которого легли его собственные специальные, конвенционные принципы. Принцип национального режима, широко используемый во многих международных документах, по сути, вытеснил т.н. минимальный международный стандарт, и в настоящее время национальный режим признается практически как общераспространенный.

3. Национальный режим в настоящее время в качестве специального принципа международного экономического права закреплен во многих международных соглашениях, как многосторонних, так и двусторонних, в сфере международной торговли (в том числе заключенных в рамках ВТО), в области защиты интеллектуальной собственности (в частности, в Бернской конвенции об охране литературных и художественных произведений 1886 г., Всемирной (Женевской) конвенции об авторском праве 1952 г., Римской конвенции 1961 г., Парижской конвенции по охране промышленной собственности 1883 г., и др.). СССР довольно сдержанно относился к широкому применению данного принципа, ограничивая сферы его применения в международных конвен- 
циях в основном областями авторского права и прав на изобретения и товарные знаки. При этом в одностороннем порядке в СССР национальный режим предоставлялся иностранцам в отношении защиты их гражданских прав. Предоставление национального режима в одностороннем порядке иностранным гражданам закреплено и во внутреннем законодательстве РФ.

4. В настоящее время Россия стремится вступить в ВТО. В этой связи отношение к принципу национального режима в сфере торговых отношений должно изменяться, поскольку данный принцип является одним из базовых в системе ВТО, несмотря на то, что зачастую использовался и используется рядом стран (например, США) в собственных интересах в ущерб другим государствам.

5. Можно дать следующее определение национальному режиму в качестве специального принципа международного экономического права. Принцип национального режима - принцип конвенционного характера, в соответствии с которым государство предоставляет, как правило, в оговоренных пределах на своей территории (обычно включая административно-территориальные образования) иностранным личам тот же режим, что и для начиональных лич, в частности в области внешней и внутренней торговли, налогообложения, применения начионального законодательства, судебной зачиты, финансовых, административных, транспортных и т.n. правил.

6. И, наконец, значение принципа национального режима можно определить, согласившись с В.М. Шумиловым: данный принцип содействует конвергенции правовых систем разных государств, которая прослеживается в мире ${ }^{65}$. Однако стоит оговориться, что национальный режим содействует конвергенции лишь косвенно и на весьма далекую перспективу, при этом само понятие конвергенции должно рассматриваться в широком смысле слова как процесс постепенного сближения экономических, политических и идеологических различий разных общественных систем.

\footnotetext{
${ }^{65}$ См.: Шумилов В.М. Указ. соч. С. 93; См. также: Шумилов В.М. Международное экономнческое право. М., 2002. С. 220; Шумилов В.М. Международное публичное экономическое право. М., 2001. С. 131; Международное право / отв. ред. В.И. Кузнецов. М., 2001. С. 603.
} 